\title{
QUANDO A PANDEMIA ATINGE O INTERIOR DO LAR
}

\author{
Rafael Zaneripe de Souza Nunes \\ Lisiane Tuon Generoso Bitencourt
}

DOI: http://dx.doi.org/10.18616/intcov03

A pandemia do novo coronavírus trouxe diversas mudanças no cotidiano da população. As rotinas, antes estabelecidas, abruptamente assumiram um novo caráter com as medidas de isolamento social, levando a modificações significativas na dinâmica intrafamiliar. $\mathrm{O}$ lar, ou a ideia que se tem, traz uma conotação de ambiente protetor, acolhedor e caloroso, que no meio do caos vivenciando, poderia trazer algum conforto e consolo, seja por meio das paredes conhecidas dos cômodos ou da relação com os que ali vivem. A realidade tende a se mostrar diferente em muitos lares brasileiros, cuja morada é permeada de sofrimento, tensão e agressividade, adoecida pela famigerada violência doméstica.

A manifestação dessa triste realidade ocorria muito antes da covid-19 ou das medidas de isolamento (quiçá uma pandemia anterior a que estamos vivendo). Pode-se classificá-la como uma "pandemia doméstica" ou "caseira", aquela que adoece o lar, as relações, a vida, que tira seu calor e sua razão de ser chamada de lar. Nesses momentos, em que se vive uma realidade que a população se encontra a maior parte do tempo nos domicílios, o medo e raiva se tornam uma mistura tóxica, potencializando os episódios de violência, principalmente no interior das residências. Os vulneráveis que estão a mercê de situações temerárias e que ferem seus direitos agora enfrentam um triplo desafio: ter o agressor (que agora está frustrado, com medo e/ou raiva) mais tempo dentro do domicílio; temer o risco de contaminação fora de seu domicílio em decorrência da situação pandêmica; e a dificuldade de estabelecer contato com o ambiente externo e vice-versa, na busca de auxílio pela situação enfrentada. 
Nesse período em especial, mulheres e crianças estão mais suscetíveis a violência doméstica e intrafamiliar (GARCIA; DUARTE, 2020), o que levanta a questão: quais as articulações da esfera pública frente a essa situação? Giovanella (2020) argumenta que o enfoque comunitário e territorial da Atenção Básica no Sistema Único de Saúde (SUS) pode contribuir no enfrentamento a pandemia. Nessa perspectiva, tal enfoque abriria um leque de possibilidades, frente aos efeitos secundários das atuais circunstâncias, no caso, o aumento potencial de violência doméstica. Inclusive, a articulação das redes do Sistema Único de Assistência Social (SUAS) e SUS pode ser uma forte aliada no enfrentamento dessa conjuntura, pois por meio da intercessão dos sistemas na esfera da gestão pública, é possível ampliar o número de notificações e intervenções em ambientes acometidos desse mal.

A violência doméstica é muitas vezes uma demanda invisível e subestimada pelos profissionais, e nesse cenário pandêmico, o agressor acaba achando uma camuflagem ainda melhor para seus atos cruéis: o isolamento. Embora a medida de isolamento seja necessária, os entes públicos não podem deixar de pensar sobre as consequências advindas de sua aplicação, sendo que elas não são puramente econômicas. A violência dentro dos lares é mais frequente do que se pensa que é, e mobilizar-se nesse momento não é apenas possibilidade, é dever.

\section{REFERÊNCIAS}

GARCIA, Leila Posenato; DUARTE, Elisete. Intervenções não farmacológicas para o enfrentamento à epidemia da covid-19 no Brasil. Epidemiologia e Serviços de Saúde, Brasília, DF, v. 29, n. 3, p. 1-4, 2020.

GIOVANELLA, Ligia. APS na rede de enfrentamento à covid-19. Rio de Janeiro: ENSP/ Editora da Fiocruz, 2020. Disponível em: https:/www.arca.fiocruz.br/ handle/icict/40918. Acesso em: $1^{\circ}$ jun. 2020. 